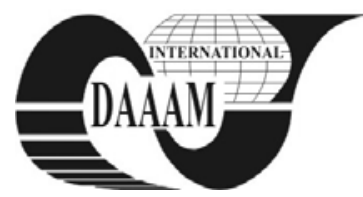

Annals of DAAAM for 2011 \& Proceedings of the 22nd International DAAAM Symposium, Volume 22, No. 1, ISSN 1726-9679 ISBN 978-3-901509-83-4, Editor B. Katalinic, Published by DAAAM International, Vienna, Austria, EU, 2011 Make Harmony between Technology and Nature, and Your Mind will Fly Free as a Bird Annals \& Proceedings of DAAAM International 2011

\title{
IMPACT OF TECHNOLOGY ON DEVELOPMENT OF RETAIL SERVICES
}

\author{
MARKOVIC, M[ilivoj]; KNEGO, N[ikola] \& VOUK, M[arko]
}

\begin{abstract}
Authors analize the role of technology in development of retail services. Influence of different types of technology is considered with their benefits for consumers as well as to retailers. Special attention is given to major impediments for increased use of technology mediated services, especially on consumer sides. Recommendations are given to managers so they can ease the process of switching customers from classic service delivery processes to service delivery via technology.

Key words: retailing services, technology, consumer satisfaction
\end{abstract}

\section{INTRODUCTION}

Almost all modern economies are service economies. The growt rate of service sector greatly surpasses the growth rates of agriculture and industry sector. Among the plethora of services, in developed economies the most dynamic ones are knowledge based services. Two key driving forces behind knowledge based services are advances in tehnology and highy educated workforce.

All services can be grouped into four distinctive categories. Relative contribution of technological advances to development of each scecific category can be assessed (Lovelock \& Wirtz, 2011). People processing services (health care, lodging etc.) and possession processing services (transportation, dry cleaning etc.) are focused on tangible actionst directed at people or their possetions. On the other hand, mental stimulus processing (aducation, advertising etc.) and information processing services (banking, accounting etc.) are focused and intangible actions.

Technological advances have greatly influenced development of all four types of services. Bill paying using mobile phones, shipment tracking over the internet and custom tailord advertising messages received via email are just a few of the classical examples.

The aim of this paper is to review contemporary literature on retailing services with special focus on the impact of technology on their evolution. Analysis of past trends is presented as well as a discussion on possible future developmet paths. In the following chapter we present an overview of dominant technological soulutions used in retail services delivery. Cross sectional analysis of different technologies used in different service industry types is presented. Then we present a thorough review of sef-service technologies as a special subgroup of technological solutions within the retail service landscape. Impediments to greater use are discussed next and guidances for managers are presented. Paper ends with conclusion.

\section{TECHNOLOGY IN RETAIL SERVICES - A CONCISE OVERVIEW}

With regard to technological solution used in the process of service delivery all services that use such solutions can be devide into four distinctive categories: eServices, self-services, mobile-services and remote-services (Wünderlich, 2009).
Although it is rather hard to draw exact boundries between the stated concepts it can be noticed that with differentiation in technology different concepts came into use.

eServices seems to be defined in the broadest way as "...deeds, efforts or performances whose delivery is mediated by information technology...” (Rowley, 2006). Defined like this, eServices encompass all service encounters whose delivery process is in some way based on technology, not just the internet ones as name would suggest. eServices hence preclude face-to-face interactions between consumer and sellers' employees. Consumer is directly linked to the seller organization via web site, kiosk or mobile device and uses the service without direct person-to-person interaction.

An explicit distinction between eServices and self-services is hard to find in the literatre (Dabholkar et al., 2003). Selfservices enable the consumer to produce the service without any assistance of the sellers personal. In this sense, self-services are subgroup of eServices. While some authors point out that the use of self-service is bounded by locational constraints (e.g. one has to go to the ATM or drive-in facility to use the service but internet banking or eShopping can be done from the home) other make no such distinction (Curran \& Meuter 2007).

Mobile services (mService) are a special case of eService that uses mobile phones as a vehicle for the delivery of service. In this way they are even narrower subgroup of eService than self-service, furthermore, they can be even considered a subgroup of self-services. Although smart phones have become a staple good, mobile services have not followed the same path of development.

Finally, Rowley (2006) has pointed out to new category of technology based services called remote services. In essence, remote servies characterize services where the means of the service delivery and the operator on the sellers' side are not on the same location. Expemles of remote services include: remote software updates, remote tuning of machinery etc. It is evident that remote services are mostly found in business to business context. Remote health care services are typical example in business to consumer context.

From the presented review it is easy to notice that great deal of overlap exists in the conceptual domain of technology based retail services. With acknowledgment to differences of presented concepts, in the remainder of the paper the special focus will be given to the analysis of self-service technologies. This concept most precisely encompases majority of technology based services on the consumer markets and it seams that it preveles in most recent publications (Lovelock \& Wirtz, 2011; Zeithamel et al., 2008).

\section{THE RISE OF SELF SERVICE TECHNOLOGIES}

An incentive to switch from classic service delivery to use of self service technology (SST) in the delivery process has numerous advantages for the retailers. First of all, in the long term it produces cost savings by decreasing number of employees with the same or even greater level of operational 
efficiency. It decreases variability in terms of quality. Technology, if implemented properly, is more reliably than people. Services are readily available 24 hours a day, every day. Internet banking can be used regardless of the working hours of the bank. Furthermore, most of the SSTs use some sort of propriatery software that creates a bariar to switch to other provider of service ones customers get accustomed to it.

The benefits of SSTs are not only enjoed by reailers; they are also shared by their customers as well. Main benefits customers' percive in using SSTs is time and location convenience, relatively high level of customization and fun and enjoynment they experience durith the use of SST.

\subsection{Switching to SSTs}

Research has shown that the first major problem for the retailers in their efforts to implement SSTs in every day business lies in customers' reluctance tu use them (Mick \& Fournier, 1998). Threat, anxiety and stress were found to be closely related negative emotions experienced by some consumers during initial use of SSTs. It was recorded that one of the preconditions that helped customers to swith to service delivery over SSTs was their generally favourable attitude toward technology (Dabholkar et al., 2003). On the other hand, some customers simply view services as a social experience and do no consider switching to SSTs.

In general it can be said that customers prefer SSTs when they fulfil or exceed their expectations. SSTs are particulary popular with experienced users as they can fully exploit the benefits of technology. At the same time it would seem that majority of dissatisfaction from using SSTs arises due to the lack of service recovery systems. Once the service failure occurs in the classical service encounter, sellers' staff is readily available to help the consumer. During the use of SSTs, no such option exists. Customers are usually left with a toll free number or an automated service to lodge their complaint.

It is worth noting that besides failure in the SSTs delivery process, customers also experience frustration and dissatisfaction when delivery processes are porly designed. Web pages, for example, are not always user friendly, server connections are sometimes very slow and internet lines can break by no guilt of the service providers. Even the customers can sometimes be their own couse and source of dissatisfaction by not adapting to the right procedures of use. Research shows that even when consumers are to blame for the problems they experience it is very likely that they will attribute greater guilt for their problem with SSTs to the retailer then themselwes (Bendapudi \& Leone, 2003).

\subsection{Guidelines for the retailers}

Retailers can greatly aid the process of adoption of SSTs to consumer if they follow some basic guidelines. If they force the consumers to use SSTs (e.g. all other service delivery modes are canceled) the will likely cause negative attitudes toward the use of SSTs. Retailers should also offer a fall-back (e.g. an assistant should be readily available to aid the consumer in case that help is needed) options for consumers who are not satisfied with the SSTs performance (Reinders et al., 2008).

It is important for retailers to understand the way in which customers behave in a virtual serviscape and what are their preferences. Aksoy et al. (2006) have shown that complex decision processes used by electronic recommendation agents (software created to help consumerd during eShopping by offering a list of recommended products based on perceived consumer preferences) do not produce results that correspond to choices that consumers would have made. Consumers are found to use simple rule of thumb processes to make a decision that is hard to artificially imitate by contemporary software.

Bitner (2001) has offered a few quideliness for managers that will ensure an easier adoption of SSTs by the consumers. Before everything else, managemante must ensue that SSTs will work reliably. Secondly, they must analyze benefits of using SSTs by consumers instead of using the classical processes of delivery. And lastly, management must install a procedure for recovering if the technology fails and the service is not delivered. By following these short guidelines management will increase not only adoption of the SSTs by the customer but also their increased future use and positive word of recommendation from current customers to non-users.

\section{CONCLUSION}

Technology mediated services will undoubtedly be advanced in years to come. While technology offers various possibilities for the design of service delivery process, managers should devote more attention to consumers' readiness to switch from classical service delivery processes to new ones, mediated by technology. Management should also provide detailed assistance throughout the switching process. SSTs should be implemented gradually, offering incentives to customers. Furthermore, it is necessary for management to predict possible failures in technology and prepare ready made procedures for service recovery when such an event occurs.

Following simple guidances suggested in this paper, which are based on thourough literature review, will undoubtebly increase consumer satisfacition and lead to greated consumer loyalty and profitability through the use of SSTs.

\section{REFERENCES}

Aksoy, L.; Bloom, P.N.;Lurie, N. \& Cooil, B. (2006). Should Recommendation Agents Think Like People?, Journal of Service Research, Vol. 8, No. 4, pp. 297-315, 1094-6705

Curran, J. \& Meuter, M. (2007). Encouraging Existing Customers to Switch to Self-Service Technologies: Put a Little Fun in Their Lives, Journal of Marketing Theory and Practice, Vol. 15, No. 4, pp. 283-298, 1069-6679

Bitner, M.J. (2001). Self-Service Technologies: What Do Customer's Expect?." Marketing Management, Vol. 10, No. 1, pp. 10-11, 1061-3846

Bendapudi, N. \& Leone, R.P. (2003). Psychological Implications of Customer Participation in Co-Production, The Journal of Marketing, Vol. 67, No. 1, pp. 14-28, 15477185

Dabholkar, P.A.; Bobbitt, M.L. \& Lee, E.J. (2003). Understanding consumer motivation and behavior related to self-scanning in retailing: Implications for strategy and research on technology-based self-service, International Journal of Service Industry Management, Vol. 14, No. 1, p. 59-95, 0956-4233

Lovelock, C. \& Wirtz, J. (2011). Services Marketing: People, Technology, Strategy, Pearson Education, 978-0-13611874-9, Upper Saddle River, New Jersey

Mick, D. \& Fournier, S. (1998). Paradoxes of Technology: Customers Cognizance, Emotions, and Coping Strategies, Journal of Consumer Research, Vol. 25, No. 2, pp. 123146, 0093-5301

Reinders, M.J; Dabholkar, P.A. \& Frambach, R.T (2008). Consequences of Forcing Consumers to Use TechnologyBased Self-Service, Journal o Service Research, Vol. 11, No. 2, pp. 107-123, 1094-6705

Rowley, J. (2006). An analysis of the e-service literature: towards a research agenda. Internet Research, Vol. 16, No. 3, pp. 339-359, 1066-2243

Wünderlich, N. (2009). Acceptance of Remote Services: Preception, Adoption, and Continued Usage in Organizational Setting, Gabler, 978-3-8349-1957-1, Weisbaden

Zeithamel, V.; Bitner, M.J. \& Gremler, D. (2008). Services Marketing, McGraw-Hill/Irwin, 978-0-07-338093-3, New York, United States 